\title{
SOUTHERN BRASÍLIA BELT (SE BRAZIL): TECTONIC DISCONTINUITIES, K-AR DATA AND EVOLUTION DURING THE NEOPROTEROZOIC BRASILIANO OROGENY
}

\author{
CLAUDIO DE MORRISON VALERIANO ${ }^{1,4}$, WILSON TEIXEIRA ${ }^{2,4}$, MONICA HEILBRON $^{1,4}$ \\ AND LUIZ SERGIO AMARANTE SIMÕES ${ }^{3,4}$
}

\begin{abstract}
This paper focuses the tectonic evolution of the southern Brasília belt, with emphasis on the Furnas segment, along the $21^{\circ} \mathrm{S}$ parallel. The uppermost structural unit (Passos Nappe - PN) comprises a highly deformed metasedimentary succession interpreted as a fragment of the Neoproterozoic passive margin of western São Francisco craton. An inverted metamorphic gradient ranging from greenschist to lower granulite facies of medium to high-pressure regime characterizes the PN as relict of a subduction zone. The External Domain displays a complex imbrication of basement rocks (Archean Piumhi greenstones, a turbiditic graywacke succession and a calc-alkaline granitoid suite) with undated siliciclastic low-grade metasedimentary rocks. The São Francisco Craton (SFC) comprises pre-1.8 Ga basement rocks covered by anchimetamorphic Neoproterozoic carbonatic shallow marine platform deposits of the Bambuí group. The Brasiliano thrust stacking generated a coarse clastic influx of molassic character on the foreland zone of São Francisco Craton, coeval with the exhumation of the External Domain thrust sheets. New K-Ar determinations on mineral separates are presented and interpreted among previous data. The SFC basement rocks display Paleo- to Mesoproterozoic cooling ages. The allochthonous units, in contrast, display K-Ar ages within the 560-675 Ma range. Brasiliano thrust stacking is therefore interpreted to have taken place onto a "cold" São Francisco craton foreland, in a thin-skinned style, as basement rocks were not heated enough to have their K-Ar systems reset during the allochthony.
\end{abstract}

Keywords: Brasilia Belt, K-Ar, Neoproterozoic, thrust tectonics, Brasiliano orogeny

\begin{abstract}
INTRODUCTION The Brasília belt is an important tectonic element of the Tocantins orogenic Province, developed during the Neoproterozoic Gondwana assembly, through convergence between the Amazonian, São Francisco and a third cratonic block presently covered by the Paraná Basin (Brito Neves et al. 1999). The southern portion of Brasilia belt (Fig. 1) has its eastern tectonic elements consistently thrusted eastwards towards the border of São Francisco craton (SFC). Southwards, the Ribeira belt, displaying NE-SW structural fabric along the Atlantic coast and a relatively younger tectonic development, with metamorphic peaks dating around 580 and $530 \mathrm{Ma}$ (Machado et al. 1996) truncates it.

This article presents an overview of the tectonic organization of southern Brasilia belt, with emphasis on the Furnas segment, along the $21^{\circ} \mathrm{S}$ parallel. In that region, the Passos nappe displays low to highgrade Brasiliano metamorphism and was exhumed and thrusted at least $250 \mathrm{~km}$ onto a relatively cold foreland zone (eastern border of the São Francisco craton) as thin-skinned tectonic slices. K-Ar data help to constrain the timing and thermal conditions of allochthony.
\end{abstract}

TECTONIC ORGANIZATION OF SOUTHERN BRASÍLIA BELT Three major imbricated tectonic domains contrast in structure, metamorphism and lithology (Fig. 1). The Internal Domain comprises the uppermost metamorphic nappes. They define three synformal structures, named from north to south Araxá, Passos and Luminárias nappes and are composed by Neoproterozoic passive margin metasedimentary successions with complex polyphase deformation, including distinct recumbent-style early folding. These nappes attained metamorphic conditions from greenschist to highpressure granulite facies and thus have been regarded as tracers of a Brasiliano suture zone (Campos Neto \& Caby 1999). In the Araxá nappe, an ophiolitic melange was identified by Brod et al. (1991), pointing to the involvement of oceanic assemblages in the Neoproterozoic allochthony. The Luminarias Nappe is covered by the Socorro-Guaxupé allochthon, composed by relatively lower pressure granulites. To the west, the Paraná basin covers the Internal Domain, so overlying tectonic domains are hidden. The External Domain is tectonically imbricated, composed of mainly greenschist facies siliciclastic metasediments related to proximal passive margin environments. Basement thrust-sheets are also present. The Cratonic Domain comprises basement outcrops of the São Francisco craton, of Archean to Paleoproterozoic age, and autochthonous low metamorphic grade sedimentary cover, of post-1.8 Ga ages, with varied degrees of deformation (Ribeiro et al., 1995).

GEOLOGY OF THE FURNAS SEGMENT Internal Domain (Passos Nappe) In the Furnas segment (Fig. 2), the Internal Domain is represented by the Passos Nappe (PN), which displays a metasedimentary succession (Araxá group) containing abundant metabasic intercalations. A Lower Unit displays metapelites with marble lenses and quartzite beds, interpreted as prograding shelf sedimentation. A transitional contact with the Upper Unit, with paragneisses and feldspathic schists, probably marks reactivation of extensional stresses, which led to the erosion of granite-gneissic basement sources. Frequent intercalations of continental tholeiitic metabasalts are also characteristic. To the top of this transition, predominant metapelites with thin beds of paragneiss, calc-silicate rocks and spessartite-quartz metachert indicate deep marine environments. The geochemistry of intercalated metabasic rocks is indicative of progressive lithospheric extension, starting with the predominance of continental metabasalts, tending towards the top to a predominance of E-MORB type metabasalts (Valeriano \& Simões 1997).

The PN displays a sole thrust always below the main quartzite level of the Lower Unit. Lithologic contacts (enveloping surfaces of the relict bedding planes) at map scale are subparallel to the basal thrust surface, regardless of pervasive tight intrafolial recumbent main phase folding. This feature played important role during the tectonic transport, in which the basal metapelites, overlain by relatively competent quartzite beds, acted as a crustal detachment zone. The internal deformation comprises early sin-metamorphic low angle shear processes, which originated tight to isoclinal folds with gently $\mathrm{W}$ to WNW dipping axes and penetrative axial plane foliations related to progressive refolding of early foliation. Associated stretching lineation is always subparallel to fold axes. Abundant shear sense indicators show unequivocal tectonic transport towards between $\mathrm{E}$ and $\mathrm{SE}$ directions. This main deformation is interpreted as the initial stage of crustal shortening related to a Neoproterozoic subduction zone, followed by the formation of the basal detachment zone and final thrust-emplacement onto the External Domain (Simões 1995). The thrust-driven ascension of the Passos nappe must have been relatively fast, indicated by the preservation of an inverted medium to highpressure metamorphic gradient (Simões 1995), ranging from upper greenschist to lower granulite facies, with metamorphic zonation nearly parallel to bedding and basal thrust. The post-metamorphic peak deformations of the PN include two sets of gentle to open folds with steep axial planes, one with NW trending axes and a later phase with $\mathrm{N}-\mathrm{S}$ axes.

External Domain This tectonic domain is a foreland thrust-fold belt with four imbricated main lithologic associations (Valeriano et al. 1995), all displaying greenschist facies metamorphism (chlorite zone), that is:

i) the Serra da Boa Esperança unit, a siliciclastic succession of still undefined age. Typical lithology includes coarse orthoquartzites, sericitic phyllites and quartz-metaconglomerates with subordinated iron formation and carbonaceous metashales; 


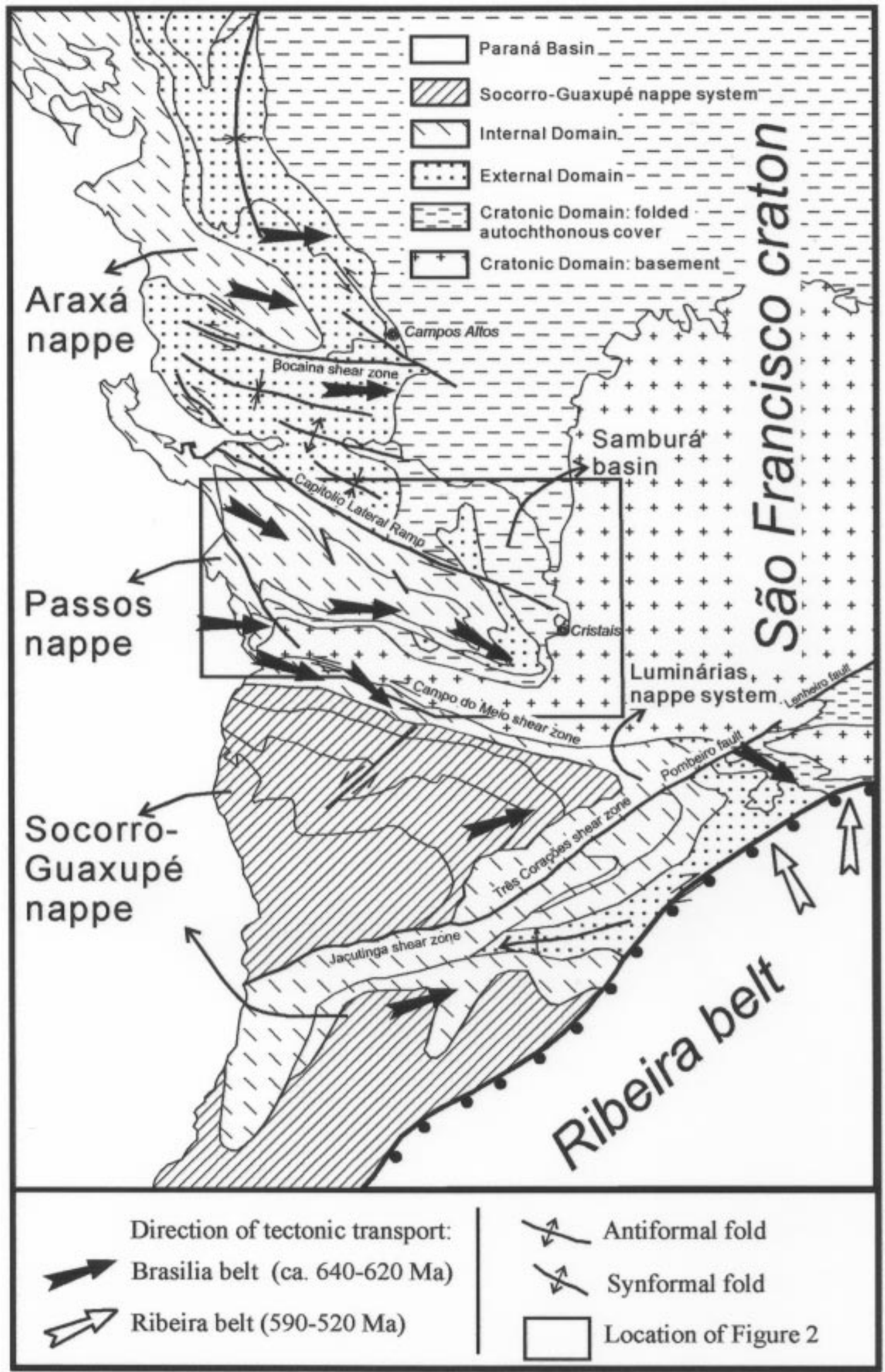

Figure 1: Main structural elements of southern Brasilia belt and adjacent geotectonic units. Compiled from Schrank et al. (1990), Morales et al. (1993), Ribeiro et al. (1995), Valeriano et al. (1995), Seer (1999) and Simões (1995). 
ii) an Archean granite-greenstone association, with metakomatiites containing relict pillows and spinifex texture, in association with mafic to felsic metavolcanic and metasedimentary rocks (Schrank 1982). U-Pb zircon dating of a gabbro sill within the volcanic sequence yielded an upper intercept at $3116 \pm 10 \mathrm{Ma}$ (Machado \& Schrank 1989). At the Piumhi town area, granitoid rocks are clearly intrusive in the volcanic rocks. South of Piumhi, granitoid rocks predominate over the greenstones. South of Santo Hilario, an expanded deformed calc-alkaline granitoid suite predominates, ranging from gabbro to granite (Valeriano 1992);

iii) a thin-bedded turbidite sequence of low metamorphic grade, and iv) minor thrust slices of the Bambuí Group slates.

In addition to the main continuous exposures under the Passos nappe, eleven small klippen were also mapped overlying the Cratonic Domain. The structural evolution of the External Domain contrasts with that of the other tectonic domains. Individual thrust sheets display a deformational fabric due to an intense $\mathrm{N}$-verging low-angle shear tectonic transport marked by a stretching lineation and associated shear sense indicators. Valeriano et al. (1995) suggest that this fabric could be a relict of a pre-Brasiliano crustal shortening event. These previously deformed rock were involved in the Brasiliano east-vergent thrust stacking, at shallow crustal levels, on top of the Cratonic Domain. The Brasiliano deformation produced upright chevron folds

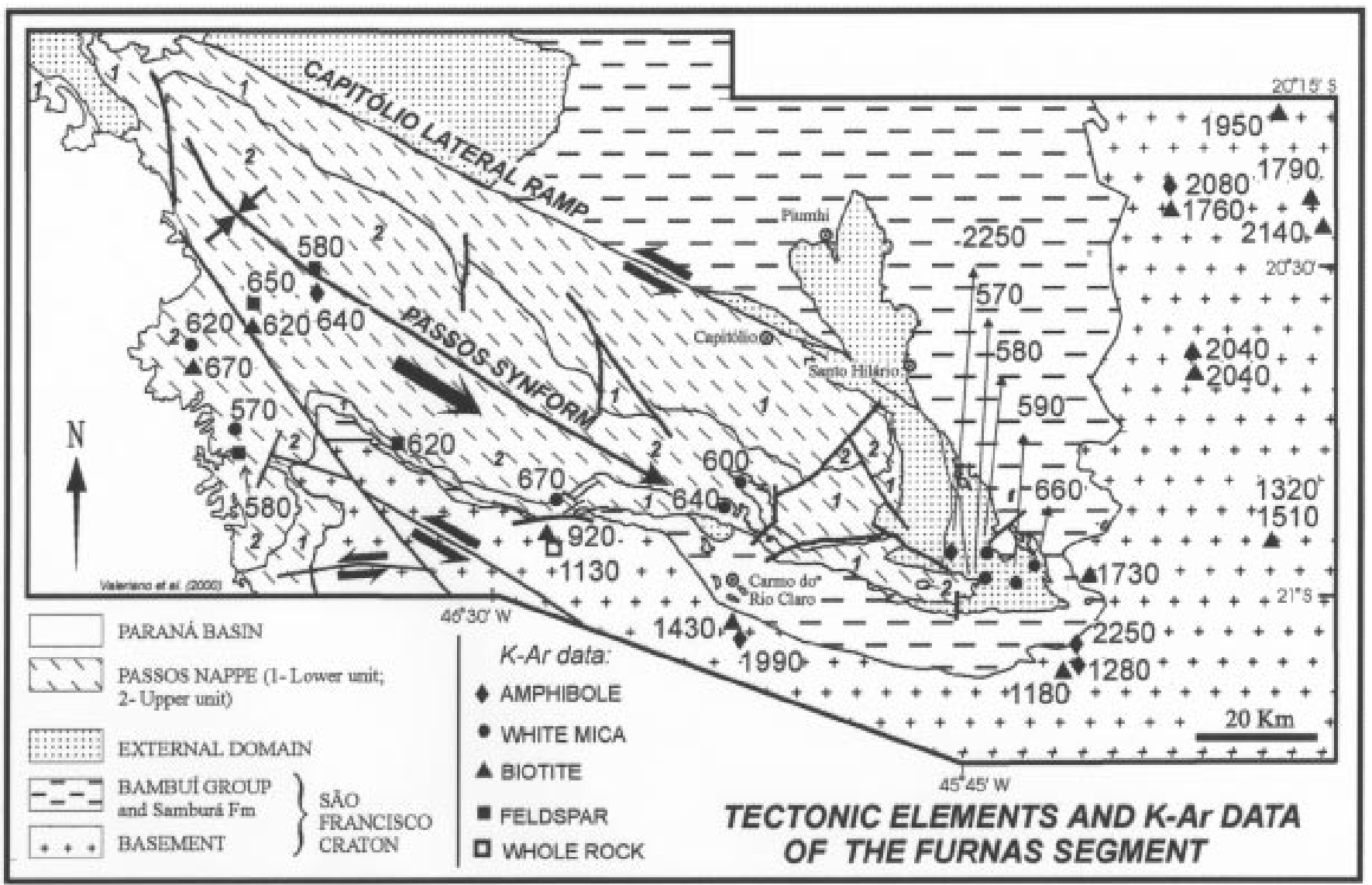

Figure 2 - Tectonic sketch of the Furnas segment of southern Brasilia belt. K-Ar data from Correia et al. (1982), Machado Filho et al. (1983), Teixeira (1982, 1985), Teixeira et al. (1989) and this paper.

Table 1 - Analytical data of new K-Ar determinations from the Furnas segment of the Brasilia belt, performed at the CPGeo-USP (Valeriano 1992).

\begin{tabular}{|c|l|l|c|c|c|c|c|}
\hline Age $(\mathbf{M a})$ & Mineral & Rock type & $\begin{array}{c}\text { Sample } \\
\text { number }\end{array}$ & UTM coordinates & $\mathbf{\% ~ K}$ & $\begin{array}{c}\text { rad }^{\mathbf{4 0} \mathbf{A r} \mathbf{x}} \\
\mathbf{1 0}^{\mathbf{6}} \mathbf{\text { atm. }} \\
(\mathbf{c c S T P} / \mathbf{g})\end{array}$ & $\begin{array}{c}\% \\
\mathbf{A r}^{\mathbf{4 0}}\end{array}$ \\
\hline $595 \pm 7$ & White mica & Quartzite & FU-3-C & $363.20-7713.25$ & 8.4555 & 231.72 & 5.98 \\
\hline $600 \pm 13$ & White mica & Quartzite & CRC-1-16 & $386.95-7694.70$ & 8.2755 & 228.65 & 3.10 \\
\hline $637 \pm 17$ & White mica & Quartz-phyllite & CRC-2-33 & $383.30-7691.15$ & 7.7239 & 228.84 & 5.65 \\
\hline $673 \pm 27$ & White mica & Quartz-mica schist & ALP-1 & $354.80-7693.60$ & 7.3508 & 232.30 & 2.29 \\
\hline $567 \pm 7$ & White mica & Quartzite & BE-5-131 & $427.10-7680.80$ & 7.9269 & 205.05 & 6.03 \\
\hline $575 \pm 11$ & White mica & Quartzite & CRI-C-62 & $426.40-7684.60$ & 7.0482 & 185.18 & 8.25 \\
\hline $588 \pm 15$ & White mica & Quartz-phyllite & CRI-CL-4a & $431.90-7679.60$ & 7.2673 & 196.19 & 15.16 \\
\hline $659 \pm 8$ & White mica & Granitic phyllonite & BE-2-85 & $433.20-7682.10$ & 7.0409 & 217.43 & 17.32 \\
\hline $2251 \pm 26$ & Hornblende & Dioritic gneiss & CRI-1090 & $419.80-7684.85$ & 0.4973 & 86.50 & 4.16 \\
\hline $1727 \pm 100$ & Biotite & Granite & CRI-CWM-a & $445.00-7680.30$ & 0.6821 & 76.33 & 20.50 \\
\hline
\end{tabular}




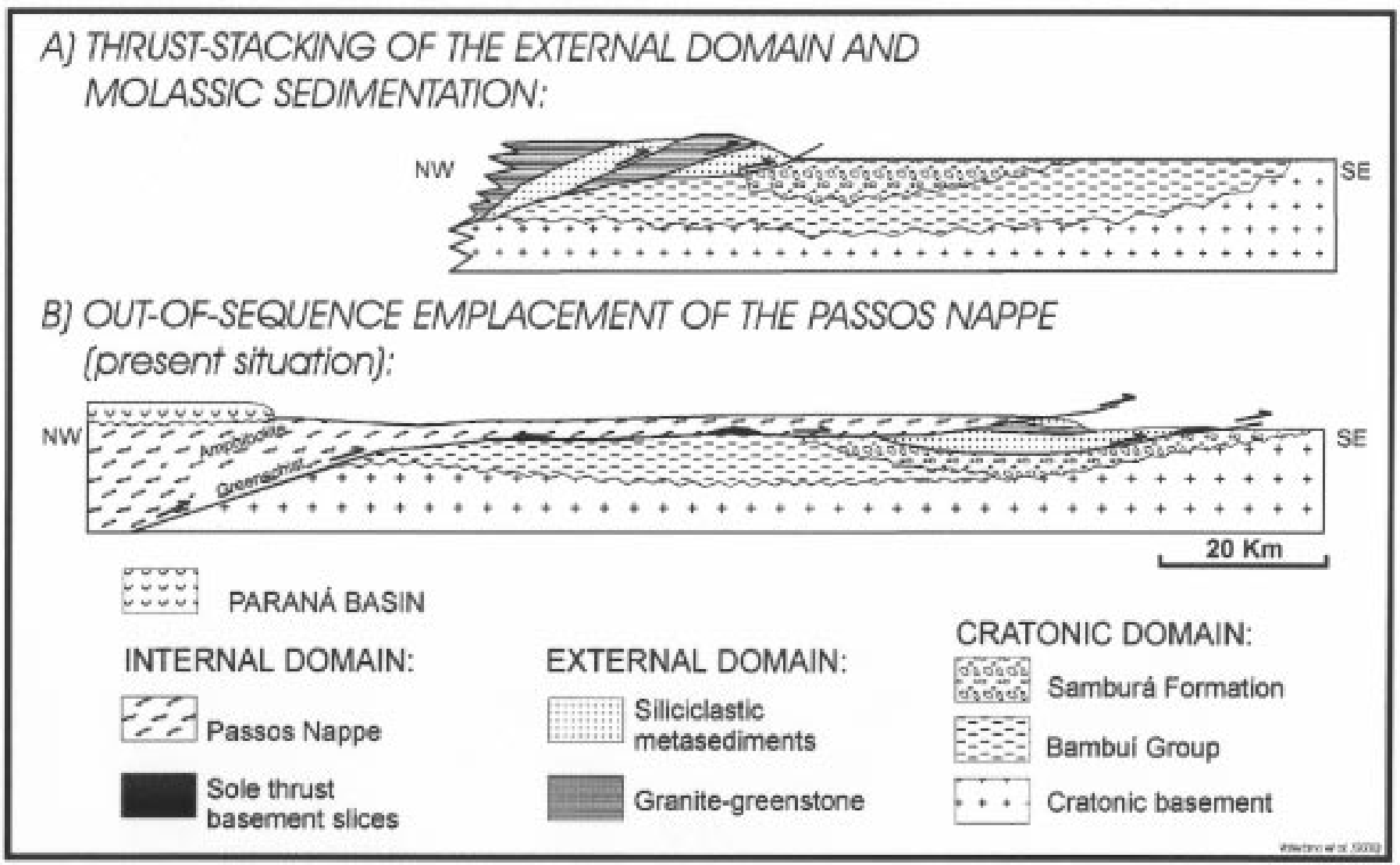

Figure 3 - Evolution of thrust-stacking events along the Furnas segment of southern Brasilia belt.

overprinting the previous subhorizontal foliation containing the N-S lineation. These folds are typically associated with brittle-ductile deformation, such as inverse and vertical faults, kink-bands, and intense jointing along axial surfaces. Overprinting of these $\mathrm{N}-\mathrm{S}$ folds, by late and E-W to NW-SE folds, resulted in dome-and-basin interference patterns.

Cratonic Domain The autochthonous basement rocks, covered by the Bambuí group, extend continuously from the SW border of the SFC, along the southern limb of the PN (Fig. 2). This sector comprises an association of Archean to Paleoproterozoic migmatite-granite complexes with greenstone-belt remnants. South of the PN, moderate to high angle ductile and brittle shear zones overprint and obliterate previous structures, defining a major NW-SE sinistral strike-slip crustal discontinuity, referred to as the Campo do Meio Shear Belt by Morales (1993). The Bambuí group displays a deformational gradient from undisturbed subhorizontal beds on the craton, to highly sheared tectonites underneath the External Domain (Alkmin et al. 1989). As in the overlying domains, the overprinting of two sets of late open folds and kinks, on the slaty cleavage, is also registered. A Brasiliano sincompressional foreland basin is represented by the Sambura Formation, which overlies discordantly the Bambuí Group and is tectonically covered by the external allochthons. The most representative lithotype is a polimict metaconglomerate that occurs along the basal portion of repetitive erosive upward-fining sedimentation meter thick cycles, interpreted as sub-aqueous fan deposits related to the erosion of the advancing thrust front of the Brasília belt (Valeriano 1992, Castro \& Dardenne 1996). Clast compositions show clear provenance from the External Domain and Bambuí group rocks.

K-Ar DATA AND TECTONIC IMPLICATIONS New K-Ar determinations (Table 1) in addition to pre-existing data indicate that the regional cooling pattern constrains the timing of exhumation of the allochthonous domains, with implications regarding the thermal state of the foreland during orogeny.
In the External Domain, white mica from three samples of Serra da Boa Esperança quartzites (Table 1) yield a relatively narrow range of $588 \pm 15$ to $567 \pm 17 \mathrm{Ma}$ apparent ages, related to the Brasiliano tectonic imbrication. A significantly older white mica age of $659 \pm 8$ Ma from a basement granitoid-phyllonite thrust sheet (sample BE-2-85, Table 1 ), is interpreted as a mixed age, due to the presence of non recrystallized coarse primary mica. Hornblende from an orthogneiss sample (CRI-1090) within the granite-greenstone thrust slice yielded a $2251 \pm 26 \mathrm{Ma}$ age. Although isolated, this value is compatible with the chlorite zone metamorphism in the External Domain, which was not high enough to reset older K-Ar hornblende systems.

In the Passos Nappe, available K-Ar age determinations (Correia et al. 1982, Machado Filho et al. 1983, Valeriano 1992) constrain its regional cooling within the 674-640 and 673-566 Ma time intervals obtained from hornblende/biotite and white mica, respectively. It is noteworthy that the youngest white mica ages from the NP are closely coincident with those of the External Domain (ca $570 \mathrm{Ma}$ ). This may be interpreted as the cooling age of the allochthons under $350 \pm 50^{\circ} \mathrm{C}$, which is the estimated closing temperatures of argon in white mica (Hanes 1991).

Teixeira $(1982,1985)$ has studied the K-Ar cooling pattern of basement rocks from the Cratonic Domain of the southern SFC area in detail. The widespread apparent ages at ca. $1.8 \mathrm{Ga}$ led the author to interpret them as the result of a conspicuous uplift and cooling event at the end of the Transamazonian collage (2.2-1.9 Ga). In the gneisses south of the Passos nappe, Teixeira et al. (1989) detected Mesoproterozoic isotopic $\mathrm{Rb}-\mathrm{Sr}$ rehomogenization (1404 $\pm 54 \mathrm{Ma}$ ) and $\mathrm{K}-\mathrm{Ar}$ hornblende ages related to the Transamazonian event $(2254 \pm 39$ and $1988 \pm 29 \mathrm{Ma}$ ), possibly related to thermal influence of the hot allochthons of the Varginha-Guaxupé nappe (Figure 1). However, relatively old $\mathrm{K}-\mathrm{Ar}$ ages indicate that, during the Neoproterozoic orogenic stage, the Cratonic Domain basement rocks were not heated enough to have their K-Ar systems reset, yielding pre-Brasiliano ages. Allochthony is therefore interpreted to have taken place onto a "cold" São Francisco craton foreland, resulting from thin-skinned nappe emplacement. 


\section{CONCLUDING REMARKS}

As recorded by the main deformation/metamorphism in the Internal Domain of the Passos nappe, crustal shortening took place first at medium to lower crustal levels. Through correlation with the adjacent Araxá nappe, where Seer (1999) obtained Sm-Nd whole mineral isochrons, this metamorphic event took place at ca $630 \mathrm{Ma}$. With initiation of thrust stacking and exposure of the External Domain thrust sheets (Fig. 3a), coarse clastic influx of molassic character (Samburá Formation) took place in the foreland zone.

The late "out-of-sequence" character of thrusting and emplacement of the Passos Nappe caused the truncation of the contacts between the
External and Cratonic domains (e.g., north of Carmo do Rio Claro, Figs. 2 and 3b) and between the Bambui Group and basement rocks (west of Carmo do Rio Claro). The timing of emplacement of the Passos nappe and of the External Domain, onto the Cratonic Domain, is loosely constrained by the K-Ar data on white mica ranging 673-566 $\mathrm{Ma}$ and 588-567 Ma, respectively.

Acknowledgements The authors are thankfully indebted to the staff of the CPGeo-USP, whose suggestions brought substantial improvement to the manuscript. This article is a contribution to IGCP Project n. 419.

\section{References}

Alkmin FF., Bacelar L.A.P., Oliveira P.M., Magalhães P.M. 1989. Arcabouço estrutural da porção sul da Bacia do São Francisco. Anais do V Simposio de Geologia de Minas porção sul da Bacia do São Francisco. Anais do V Simposio de
Gerais. SBG, Núcleo de Minas Gerais, Boletim, 10:289-283.

Almeida F.F.M., Hasui Y., Brito Neves B.B., Fuck R.A. 1981. Brazilian structural provinces: an introduction. Earth Sciences Review, 17:1-29.

Brito Neves B.B. \& Cordani U.G. 1991. Tectonic evolution of South America during the Late Proterozoic. Precambrian Research, 53:23-40.

Brito Neves B.B., Campos Neto M.C., Fuck R.A. 1999. From Rodinia to Western Gondwana: an approach to the Brasiliano-Pan African Cycle and orogenic collage. Episodes 22:155-166.

Brod J.A. et al. (22 authors) 1991. Tectono-estratigrafia da Faixa Brasília na região do Alto Paranaíba. Simpósio de Geologia do Centro-Oeste 3, Cuiabá 1991. Anais... Cuiabá, 1991. SBG, pp. $155-168$

Campos Neto M.C. \& Caby R. 1999. Neoproterozoic igh-pressure metamorphism an tectonic constraing from nappe system south of the São Francisco craton, southeast Brazil. Precambrian Research, 97:3-26.

Castro P.T.A. \& Dardenne M.A. 1996. O Conglomerado Samburá (Grupo Bambuí, Neoproterozóico) e rochas sedimentares associadas no flanco leste da Serra da Pimenta, SW de Minas Gerais: um sistema de fan-delta. Geonomos, 3:35-41.

Correa C.T., Kawashita K., Girardi V.A.V. 1982. Datações Rb-Sr em Rochas Metamórfica da Região de Cássia (MG) e Considerações sobre o seu Significado Geológico. Anais da Academia Brasileira de Ciências 54:673-677.

Dardenne M.A. 1978. Síntese sobre a estratigrafia do Grupo Bambuí no Brasil Central. In Congr. Bras. Geol. 30, Recife, 1978. Anais...SBG, v. 2: 597-602.

Fritzsons Jr. O., Biondi J.C., Chaban N. 1980. Geologia da região de Piumhi (MG). In: Congr. Bras. Geol., 31. Balneário de Camboriú (SC) 1980. Anais... SBG, 5:29062917.

Hanes J.A. 1991. K-Ar and Ar-Ar geochronology: methods and applications. In: Heaman, L. \& Ludden, J.N. (Eds.) Application of radiogenic isotope systems to problems in geology. Short Course Handbook, Mineralogical Association of Canada, Toronto, v. 19:27-58.

Machado Filho L., Ribeiro M., Gonzales S.R., Schenini C.A., Santos Neto A., Palmeir R.C., Pires J.L., Teixeira W., Castro H.E. F. 1983. Geologia das folhas Rio de Janeiro (SF 23/24) escala 1:1.000.000, mapa e texto explicativo. RADAM BrasilMinistério das Minas e Energia, Rio de Janeiro, 780p.

Machado N. \& Schrank A. 1989. Geocronologia U/Pb no maciço de Piumhi - resultados preliminares. Anais do V Simposio de Geologia de Minas Gerais, Belo Horizonte. SBG, Núcleo de Minas Gerais, Boletim, 10:45-49.

Machado N., Valladares C.S., Heilbron M., Valeriano C.M. 1996. U/Pb geochronology of Central Ribeira belt: implications for the evolution of Brasiliano Orogeny. Precambrian Research 79:347-361.

Morales N. 1993. Evolução tectônica do cinturão de cisalhamento Campo do Meio na sua porção ocidental. Unpublished Thesis, IGCE-Universidade Estadual Paulista, Rio Claro, $270 \mathrm{p}$.
Ribeiro A., Trouw R.A.J., Andreis R.R., Paciullo F.V.P., Valença J.G. 1995. Evolução das bacias proterozóicas e o termo-tectonismo brasiliano na margem sul do Cráton do São Francisco. Revista Brasileira de Geociências 25:235-248.

Schrank, A. 1982. Petrologie des komatiites et des roches associées de la ceintures verte du Massif Précambrien de Piumhi (Minas Gerais - Brazil). Thèse 3ème Cycle, Université de Paris-Sud, Orsay, $270 \mathrm{p}$

Schrank A., Abreu F.R., Roig H.L., Choudhuri A., Carvalho E.D.R. 1990. Determinação dos vetores de transporte tectônico da borda sudoeste do Cráton do São Francisco. In: Congresso Brasileiro de Geologia, 36, Natal, 1990. Anais...Natal. SBG, v.5:22762283.

Seer H.J. 1999. Evolução tectônica dos grupos Araxá, Ibiá e Canastra na Sinforma de Araxá, Araxá, Minas Gerais. Unpublished Thesis, IG-Universidade de Brasília, 267 $\mathrm{p}$.

Simões L.S.A. 1995. Evolução tectono-metamórfica da nappe de Passos, sudoeste de Minas Gerais. Unpublished Thesis, IG-Universidade de São Paulo, 149 p.

Teixeira W. 1982 Geochronology of the Southern part of the São Francisco craton. Revista Brasileira de Geociências 12:268-277.

Teixeira W., Akimoto H., Siga Jr. O., Sato K. 1989. A evolução geocronológica dos terrenos granítico-gnáissico-migmatíticos ao sul da Faixa Canastra, sudoeste de Minas Gerais. Anais do V Simposio de Geologia de Minas Gerais, Belo Horizonte. SBG, Núcleo de Minas Gerais, Boletim 10:243-246.

Teixeira W. \& Figueiredo M. C. H. 1991. An outline of Early Proterozoic crustal evolution in the São Francisco craton, Brazil: a review. Precambrian Research, 53:1-22.

Teixeira W. \& Canzian F. 1994. A evolução tectonotermal proterozóica do cráton do São Francisco, com base em interpretações geocronológicas $\mathrm{K}-\mathrm{Ar}$ em rochas do seu embasamento. Boletim do IG-USP, 25:61-80.

Valeriano C.M. 1992. Evolução tectônica da extremidade meridional da Faixa Brasília região da Represa de Furnas, Sudoeste de Minas Gerais. Unpublished Thesis, IGUniversidade de São Paulo, 192 p.

Valeriano C M. \& Simões L S.A. 1997. Geochemistry of Proterozoic mafic rocks from the Passos nappe (Minas Gerais, Brazil): tectonic implications to the evolution of the southern Brasilia belt. Revista Brasileira de Geociências, 27:99-110.

Valeriano C.M., Almeida J.C.H., Simões L.S.A. Duarte B.P., Heilbron M. 1995. Evolução estrutural do domínio externo da Faixa Brasília no sudoeste de Minas Gerais: registros de uma tectônica pré-brasiliana. Revista Brasileira de Geociências, 25:221-234.

Contribution IGC-19

Received March 3, 2000 Accepted for publication March 30, 2000 